article by Mr. A. W. Exell in the Gardeners' Chronicle for June 18, p. 403. Last grown in France in 1887, its cultivation in Germany had ceased about twenty years before this date, but was continued in England, in spite of the competition first of natural and then of synthetic indigo, for many years later, the product being used in the dyeing of police and naval uniforms. The industry had, however, long been a declining one, and in 1930 only two farms, both in Lincolnshire, were growing woad. Of these, one ceased to do so last year, but the other raised a small crop; this year none at all has been grown, and Mr. Exell thinks the day of woad as a crop-plant is over, though some stock of the prepared product is still left. Woad was an expensive crop to raise, and the labour and land devoted to it have been diverted to the production of potatoes and sugar-beet.

\section{William Morgan}

Mr. Palin Elderton in a recent lecture to the Faculty of Actuaries (Trans. Fac. Act., 14, 1932, pp. 1-20) gave an interesting sketch of the life of his distinguished predecessor William Morgan, who became assistant actuary of the Equitable in 1774, actuary a year later, and retired so long after as $\mathbf{1 8 3 0}$. Morgan, who was a self-taught mathematician, owed his appointment to the famous Dr. Richard Price, whose biography he wrote (not, according to Mr. Elderton, very well), and although some of his mathematical work in connexion with joint survivorships might not have commended itself to better trained mathematicians, it was, writes Mr. Elderton, "the first serious attempt to obtain a general solution to the problems of survivorship, and had the merita great one indeed-of giving expressions that could be used to obtain arithmetical results from any mortality table".

\section{Pharmacy in Scotland}

THE forthcoming British Pharmaceutical Conference at Aberdeen on Sept. 12-16 has been the chief influence in the choice of material for the handsome special issue of the Chemist and Druggist for June 25. The majority of space has been devoted to various phases of Scottish activity from the point of view of pharmacy. An interesting account of the early history of pharmacy and the apothecary in Scotland is given by Dr. Thomas Ferguson. The cod-liver oil industry of Aberdeen and the extraction of the oil in Newfoundland are described, with useful illustrations. The appreciation of Aberdeen, the host city for the 1932 Conference, is well worth reading, and the illustrations (in photogravure) of its streets, industries, and colleges are very striking. Among the more descriptive articles is an illustrated account of the British Drug Houses, Ltd.

\section{Announcements}

ThE following Royal Society research appointments are announced: Mr. C. N. Hinshelwood, Trinity College, Oxford, and Dr. M. L. E. Oliphant, Trinity College, Cambridge, to be Messel Research Fellows. Dr. W. Hume - Rothery, Magdalen College, Oxford, No. 3271, VoL. 130] and Dr. A. J. Bradley, University of Manchester, to be Warren Research Fellows.

THE fourth Victor Horsley Memorial Lecture of the British Medical Association will be delivered by Prof. E. D. Adrian, on "The Visceral Sense Organs", at University College Hospital Medical School, Gower Street, London, W.C.1, on July 20, at 5 P.M. Admission to the lecture is free on presentation of a visiting card.

IN connexion with the centenary meeting of the British Medical Association at London, the popular lecture will be delivered by Prof. Julian Huxley in the Great Hall, University College, Gower Street, W.C.1, on July 29. The subject of the lecture will be "The Biology of Human Nature". Tickets can be obtained from the Organising Secretary, British Medical Association Centenary Offices, Tavistock House (North), London, W.C.1.

THe first Hinchley Memorial Lecture of the Institution of Chemical Engineers will be delivered on Oct. 28 by Mr. H. T. Tizard, Rector of the Imperial College of Science and Technology, on " Chemical Engineering and the Aircraft Industry ". These lectures have been inaugurated to commemorate the long and intimate association of the late Prof. J. W. Hinchley with the Institution, and will be delivered at intervals of three years.

AN International Conference on Social Work is to be held at Frankfort-on-Main on July 10-14. The main theme of the conference will be "The Family". The work of the Conference will be divided among six commissions dealing with health services, educational influences, economic insecurity, and other subjects. Arrangements for British delegates have, at the request of the British National Committee, been undertaken by the Institute of Sociology. Particulars can be obtained from Miss E. W. Spear, Secretary, Institute of Sociology, Le Play House, 65 Belgrave Road, Westminster, S.W.1.

Applications are invited for the following appointments, on or before the dates mentioned :-A head of the Department of Mathematies and Physics at the Polytechnic, Regent Street, W.1-The Director of Education, The Polytechnic, Regent Street, W.1 (July 11). A head of the Chemistry Department at Sunderland Technical College-Chief Education Officer, Education Offices, 15 John Street, Sunderland (July 11). A chemist in the Department of Government Chemist - The Government Chemist, Clement's Inn Passage, Strand, W.C.2 (July 16). A poultry pathologist in the Department of Agriculture and Horticulture at the University of Bristol-The Agricultural Officer, The University, Bristol (July 16). A biologist for the biological survey of the Hampshire Avon-The Registrar, University College, Southampton (July 16). A lecturer in chemical engineering in the Department of Chemical Engineering at the Imperial College of Science and Technology-The Registrar, Imperial College of Science and Technology, London, S.W.7 (Sept. 9). 